\title{
Effect of Fasting on Serum Non-esterified Fatty Acid Level and Subsequent Fertility in Japanese Black Heifers
}

\author{
Shozo Ohtsu, Matsuo Nakamura and Eiichi Akuzawa \\ Gunma Animal Husbandry Experimental Station \\ Fujimi-mura, Setagun, Gunma. 371-01
}

(Accepted for publication May 1, 1987)

\begin{abstract}
Summary. Three Japanese Black heifers were starved for 7 days and examined for changes in body weight and in NEFA and progesterone levels of blood, and fertility. The following results were obtained.

1. Body weight decreased in three heifers during starvation.

2. The NEFA level of blood increased markedly in three heifers during starvation.

3. After starvation of 7 days, the estrus returned on 22 days, 28 days and 62 days, respectively. As the last one was the youngest (11 months old at the start of experiment) and had the lowest body weight $(198 \mathrm{~kg})$, the starvation would have brought about the most strong effect on estrous cycle.

Although their different periods for estrous return, all three heifers conceived at the second insemination.
\end{abstract}

Jpn J Anim Reprod 33, 105-108, 1987

\section{黒毛和種未経産牛の血中遊離脂肪酸と繁殖性に及ぼす絶食の影響}

大津 昇三・中村 松夫・阿久沢栄一

群馬県畜産試験場，371-01 群馬県勢多郡富士見村大字小暮 2425

我が国における黒毛和種未経産牛の飼養状況は一部を 除き，大多数が少頭数の飼養形態であり，育成期の飼養 方法も多種多様の形をとっている。

効率的な家畜生産を考号る場合, 初産月齢は家畜の体 格に無理がない状態であれば比較的早い時期が望まし い。しかしながら育成期には, 飼養状況, 栄養の良否, 気候など自然環境的な影響を受けるため, 性成熟に到達 するまでにかなりの個体差が認められている。

育成期に拈ける性成熟は発育との関連性が重要な要因 とされ，良好な発育を示す個体は性成熟が早く，また反 対に育成期低栄養で飼養さされると性成熟も遅れ，特 に 6 １2か月齢間の発育速度は性成熟到達に強い影響を 及ぼすことが指摘され（Suzuki，1986），育成期におけ
る栄養条件は, 性機能の発現に直接影響を与える重要な 要因であることが報告されている(Kariya et al., 1986) が，その詳細はまだ未解明の部分が多い。

本研究では, 黒毛和種未経産牛を 7 日間絶食させ, 血 清中の遊離脂肪酸（NEFA）と繁殖性に与兄る影響につ いて検討した。

\section{材料と方法}

供試牛 供試牛はそれ以前に 2 回以上の正常な性周期 を繰り返していた黒毛和種未経産牛 3 頭である。No. 1 は供試時（絶食前の性周期）14.0か月齢, 体重 $279 \mathrm{~kg}$, No. 2 は同じく 15.2 加齢, $305 \mathrm{~kg}$ であり繁殖供用開 始月龃の個体である。さらに No. 3 は11か月齢, 体重 
$198 \mathrm{~kg}$ で繁殖供用開始には少し早い個体である。

絶食およびその前後の飼育方法 供試牛の絶食前は, 日本飼養標準（肉用牛, 1975年版）に従って必要養分量 が 100\%となるように，トウモロコシサイレージ，濃厚 飼料および乾草を給与した。絶食期間は 3 頭とも 7 日間 とした。No. 1 は発情発見後の 7 日間を, No. 2 は発 情発見後 2 週間経過した後の 7 日間を，さらにNo. 3 は発情発見後 1 週間経過した後の 7 日間をそれぞれ絶食 した。なお，絶食期間中飲水は自由とし，絶食終了後は 少しずつ飼料を増加して 7 日後に絶食前の給与量にし, その後は前記と同様に日本飼養標準に従って給与した。 また，絶食期間中を除き，日中（9：00〜16:00）は， 降雨時を除き運動場に放飼した。

血液の採取および体重測定 供試牛からの血液採取 は, 絶食前の性周期から絶食が終了し, その後受胎が確 認されるまで（最終授精後約65日間），1日隔に 頸静脈 から血漿用（ヘパリン入り），血清用ともに真空採血管 を使用して実施した。採血後はただちに実験室に持ち帰 り, 血漿, 血清を分離して, 分析するまで $-20^{\circ} \mathrm{C}$ に凍
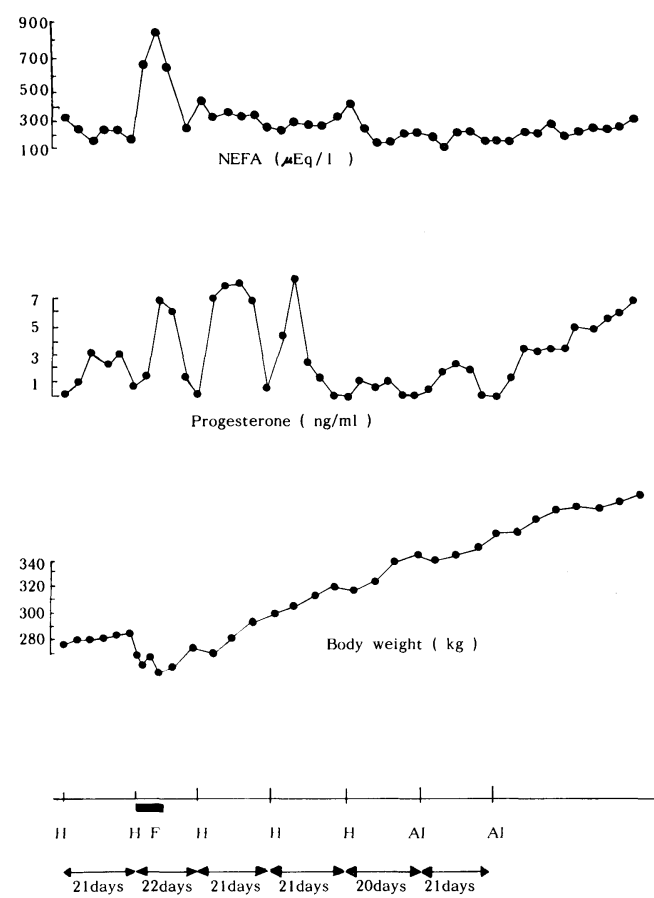

Fig. 1. Cow 1. Changes of concentrations of serum NEFA and plasma progesterone and body weight before and after fasting. The length of estrous cycle was 21 days before fasting and 22 days just after fasting.

$\mathrm{H}$; heat. AI; artificial insemination. F; fasting.
結保存した。絶食期間中の体重測定は 1 日間隔で，それ 以外の期間は 2 日間隔に牛衡器で $13: 00 \sim 14: 00$ の間 に測定した。

血液成分の検査項目および方法 採血後, 血清中の NEFA 值を ACS-ACOD 法により測定した。また繁殖 機能の回復状況を把握するために血漿中のプロゲステロ ン（P）濃度を石油ェーテルで抽出した後, 固相法によ り EIA（酵素免疫測定法）キット（西ドイッ, Biolab 社 製）で測定した（Arnstadt and Cleere, 1981; Yanaka et al., 1986)。

絶食後の繁殖成績 絶食終了後, 日中運動場に放飼し ている間の午前と午後の 1 日 2 回約 1 時間の発情観察を 実施し, 週 $2 \sim 3$ 回の直腸検査を行なって卵巣の変化を 検査した。発情発見後は直腸検査を行ない, 授精適期を 判断し, 凍結精液を用いて人工授精を実施した, 授精後の 妊娠診断は $\mathrm{P}$ 值が $1 \mathrm{ng} / \mathrm{ml}$ 以下にならないこと,およ び授精後40～60日前後の直腸検査によって判定した。
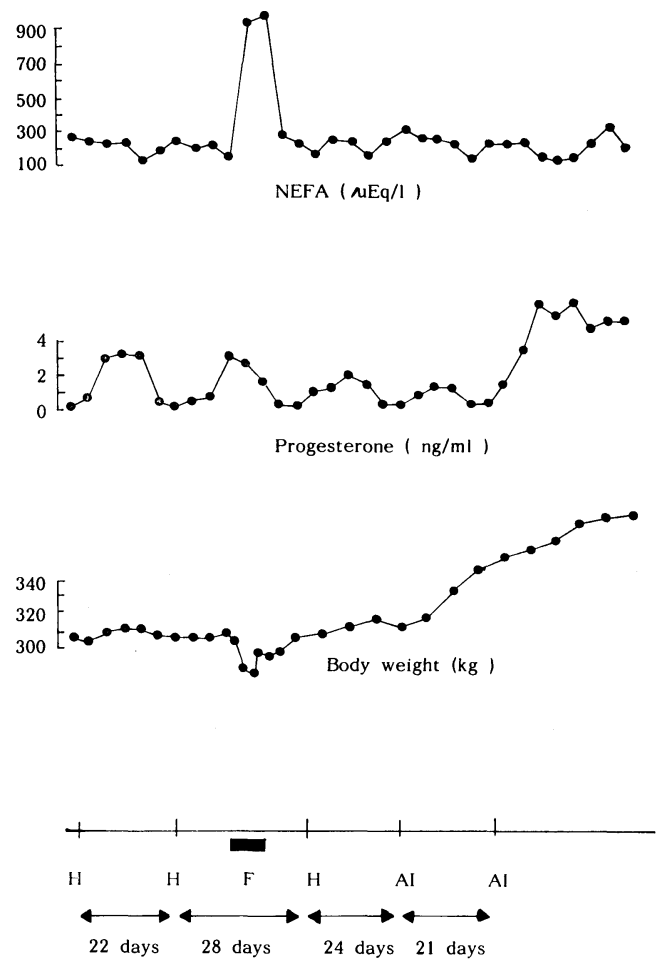

Fig. 2. Cow 2. Changes of concentrations of serum NEFA and plasma progesterone and body weight before and after fasting. The length of estrous cycle was 22 days before fasting and 28 days just after fasting.

H; heat. AI; artificial insemination. F; fasting. 

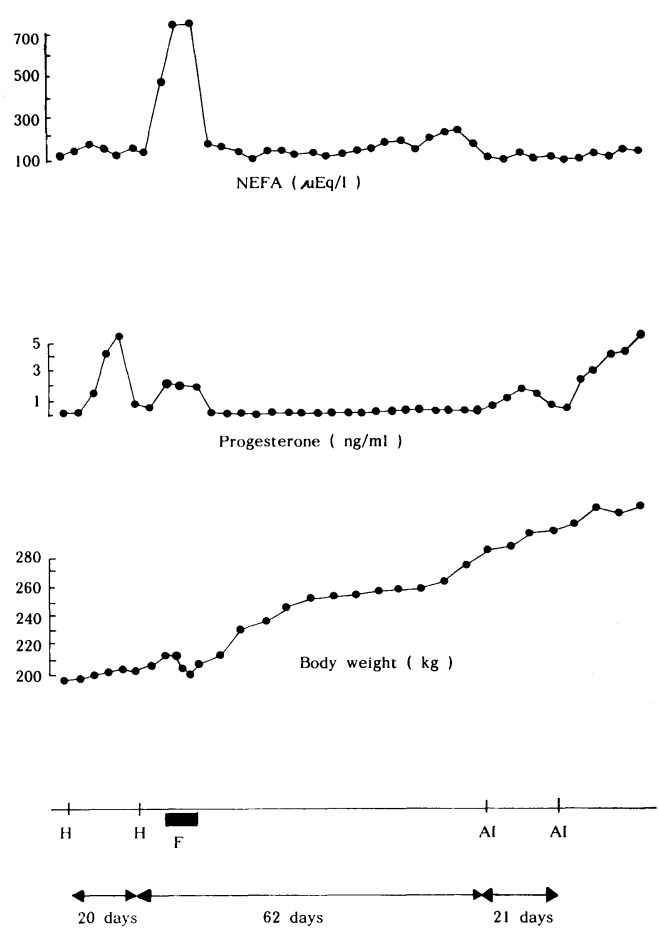

Fig. 3. Cow 3. Changes of concentrations of serum NEFA and plasma progesterone and body weight before and after fasting. The length of estrous cycle was 20 days before fasting and 62 days just after fasting.

$\mathrm{H}$; heat. AI; artificial insemination. F; fasting.

\section{結果と考察}

全期間の NEFA 值, P值, 体重, および性周期の状 況を Fig. 1 3 亿示した。供試牛の体重は絶食によっ て 3 頭とも減少した。No. 1 は $31 \mathrm{~kg}$, No. 2 は $21 \mathrm{~kg}$, No. 3 は $10 \mathrm{~kg}$ それぞれ減少し, No. 1 が最も減少し た。

血中 NEFA 值は, 絶食によって 3 頭とも急激に上昇 した，絶食負荷による血中 NEFA 值の上昇はこれまで に広く認められ (Brumby et al., 1973; Reid et al., 1977，1979）, 今回の試験結果とよく一致した, 絶食負 荷により生体内が飢餓状態となって NEFAの動員が起 こり, 体内の蓄積脂肪を NEFA の形で動員することに よって生体を維持するためのエネルギー代謝が行なわ れ，その結果として体重の減少が認められたものと思わ れる。

No. 1 は絶食後の性周期において絶食前とほとんぞ変
化がみられず，20〜22日の性周期を繰り返し血中 $\mathrm{P}$ 值も ほぼ正常と思われる值で推移した。No. 2 の絶食後の性 周期は28日目に, その後の発情も24日目に発現し, やや 性周期の延長がみられた。またNo. 3 は絶食後の性周 期が消失し，その後 62 日目に発情発現が認められ，性周 期が回帰した。この無発情期間は直腸検查により機能的 な充実した黄体は触知されず，卵巣は静止している状況 であった。またこの間の $\mathrm{P}$ 值も $0.5 \mathrm{ng} / \mathrm{ml}$ 以下の低い 值で推移した。しかしながら絶食したこれら 3 頭はいず れも2 回の授精で受胎した。

黒毛和種未経産牛 3 頭を 7 日間絶食した今回の試験に おいて，絶食後の性周期は，1頭が注漹正常とみられる 範囲内であった。他の 1 頭はやや延長し，残り 1 頭は消 失し，その後62日目に発情が回帰した，これら 3 頭は月 齢, 体重などが異なるため単純に比較することは困難で あるが，絶食後の性周期が消失した No. 3 は他の 2 頭 よりも月龄が若く，また体重も低い個体であったことが 性周期の延長に深く影響を及ぼしたものと思われた。

\section{References}

Arnstadt KI, Cleere WF (1981) Enzyme-immunoassay for determination of progesterone in milk from cows. J Reprod Fertil 62: 173-180.

Brumby PE, Anderson M, Tuckley B, Storry JE (1975) Lipid metabolism in the cow during starvationinduced ketosis. Biochem $J$ 146: 609-615.

Kariya T, Tomizuka T, Domeki I (1984) The influence of undernutrition on sexual functions in beef heifers, 1; Undernutrition from the post-pubertal first estrous cycle, 2; Undernutrition from the post-pubertal second estrous cycle. Annual Report of National Institute of Animal Industry 24: 4144. (in Japanese).

Reid IM, Colins RA, Baird GD, Roberts CJ, Symonds HW (1979) Lipid production rates and the pathogenesis of fatty liver in fasted cows. J Agric Sci 93: 253-256.

Reid IM, Stark AJ, Isenor RN (1977) Fasting and refeeding in the lactating dairy cow. J Comp Path 87: 241-251.

Suzuki $O$ (1986) Studies on the improvement in reproductive performance of Japanese Black Females. Jpn J Anim Reprod 32: 111-117. (in Japanese).

Yanaka T, Ida K, Minato Y, Yoshida S (1986) Early pregnancy diagnosis in heifer by enzyme immunoassay for progesterone in blood plasma. Jpn $J$ Anim AI Res 8: 52-55. (in Japanese). 
黒毛和種未経産牛 3 頭をそれぞれ 7 日間絶食して, 体重の推移, 血中 NEFA 值の変動, P 值の推 移および繁殖性について調査し，次の結果を得た。

1. 体重は絶食期間中 3 頭とも減少した。

2. 血中 NEFA 值は絶食期間中 3 頭とも著明に上昇した。

3. 絶食後の性周期は 1 頭で 62 日遅延し, 他の 1 頭はやや延長がみられ，残り 1 頭はほほ正常の範 用内であった。これら 3 頭はいずれも 2 回の授精で受胎した。 